\title{
CORRESPONDENCE
}

\section{LUGEON'S UNPUBLISHED INTERPRETATION OF THE STRATH OYKELL MULLIONS}

SIR,-Petrofabric studies by F. Coles Phillips (Quart. Journ. Geol. Soc. xciii, 1937), and a detailed megascopic investigation by Gilbert Wilson (Proc. Geol. Assoc., lxiv, 1953) have clearly demonstrated that the mullions of Strath Oykell are normal to the single symmetry plane of the fabric on all known scales; the mullions are therefore $b$-structures by definition. The recognition of this seems now to be generally accepted. It is therefore desirable to draw attention to the record of a remarkable unpublished interpretation by the late Professor Maurice Lugeon, who appears to have been the first investigator to interpret the Strath Oykell structures in this manner.

In the teaching collection at the University of Lausanne there is a particularly instructive specimen from Strath Oykell. It shows monoclinic folding, and the micas of the pelitic bands are parallel to the axial planes; the fold hinges form longitudinal ribs, and parallel to these there is a lineation caused by the intersection of the micas with the foliation. Last December, through the courtesy of Professor Badoux and Dr. Aubert, I saw the original catalogued description in Lugeon's handwriting :

"No. 14072. Leptynite micacée de la série des 'Moineschist' (Précambrien) présentant le Mullion ou Rodding structure des géologues écossais, soit le résultat d'une pression transversale à la direction et au plongement moyen des couches.

M. Lugeon. 12.ix.1912. R. Oykell.,"

The specimen was therefore collected at the beginning of the celebrated post-British Association excursion (Dundee, 1912), led by Peach and Horne, on which Lugeon composed his well-known "Chanson du Moine Thrust". The interest of Lugeon's description of the mullions, written before he had seen the Moine Thrust, is that their interpretation was so obvious to this alpine geologist that apparently he did not realize that these structures were not correctly understood by Highland geologists.

Grant INSTITUTE OF GeOLOGY,

DONALD B. MCINTYRE.

UNIVERSITY OF EDINBURGH.

27th January, 1954.

\section{RULES OF NOMENCLATURE}

SIR,-May I draw the attention of palaeontologists to clause 54 (1) (a) of the "Additions to, and modifications of, the Règles Internationales de la Nomenclature Zoologique approved and adopted by the XIVth International Congress of Zoology, Copenhagen, August, 1953"? This clause directs that where the name of the type genus of a subfamily, family, or superfamily has been changed because it is a junior synonym (whether objective or subjective), the name of the subfamily, family, or superfamily based upon the name of that type genus is not to be changed.

Our colleagues who sacrified their time, energies, and funds in attending the Copenhagen Congress achieved so much that is excellent and put us so greatly in their debt, that it seems ungracious to criticize their decisions. On this particular point, however, there surely must have been sharp division of opinion. The decision would have such unhappy effects in at least molluscan systematics that, if Mollusca are a fair sample, I feel palaeontologists should do all possible to prevent this clause from being incorporated in the new Rules of Nomenclature.

Some of the changes that would be required would produce completely unfamiliar monstrosities, for some family names formed on invalid objective 
synonyms have been jettisoned and ignored almost from the moment of proposal, along with the invalid nominal genus. The prospect of family and superfamily names henceforth having to be altered so as to revive and immortalize invalid junior synonyms is as daunting as the prospect of the discreditable hunt that will be started among the literature, to be the first to unearth these corpses for revival.

If all palaeontologists who object to this clause becoming part of the Rules will write to the Secretary of the International Commission on Zoological Nomenclature, Mr. Francis Hemming, 28 Park Village East, Regent's Park, London, N.W. 1, let us hope that our protests may avail. (A copy of this letter is being sent him.) If any systematist feels that in an exceptional case it is desirable to retain a well-known family name based on an invalid synonym it is always open to him to apply for the protection of the Commission on behalf of that name. Otherwise, the Rules surely should state the obvious: namely, that the legitimate name of a family (or subfamily or superfamily) is that which is formed on the valid name of the type genus.

Sedgwick Museum,

W. J. Arkell. CAMBRIDGE.

7th February, 1954.

\section{COMMENTS ON THE CARIBBEAN OLIGOCENE}

SIR,--Dr. Eames's attempt (Geol. Mag., xc, 1953, pp. 388-392) to transfer half the Caribbean Oligocene into the Miocene is remarkable for the short list of references. The works of Caudri, Drooger, Grimsdale, Hedberg, Kugler, Olsson, Renz, Vaughan, and Woodring - to name but a few-should surely be considered before claiming flatly that Miogypsina indicates a Miocene age, regardless of other considerations.

A regional transgression can be recognized in the West Indies and in northern South America, Ecuador, and Peru. The transgressive beds are marked by the appearance of new faunal elements, which include ChattianRupelian molluscs ( fide Olsson, Rutsch, Woodring, et al.), and Oligocene larger foraminifera (fide Vaughan and collaborators, Caudri, et al.). The genus Miogypsina appears in the basal transgressive beds in several countries (Drooger, et al.), and its early forms appear to be a direct development from the Lower Oligocene Rotalia mexicana. The basal Camana unconformity in Southern Peru is a local example of the regional transgression: the presence of Miogypsina (Miolepidocyclina) ecuadorensis establishes correlation with beds in Ecuador, which themselves underlie thick pre-Aquitanian shales. Hence the basal Camana beds are Oligocene and Eames's claim (op. cit.) of a Miocene age is unacceptable.

Between the time of the mid-Oligocene transgression and the first appearance of faunas of Aquitanian type, the planktonic foraminifera show a welldefined pattern of change and evolution, consistent over the whole midAmerican region. Globigerina dissimilis survived for a short time. Near its evel of extinction the genus Globigerinatella made a short-lived appearance. The Globorotalia fohsi clan appeared, with an evolutionary sequence of subspecies, but died out abruptly as $G$. menardii appeared. Orbulina universa was preceded by its ancestral form $O$. suturalis.

European paleontologists could make an invaluable contribution to transoceanic Tertiary correlation by following Colom, Grimsdale, and others in recording the ranges of these species in the European Tertiaries.

c/o International Petroleum Co.,

R. M. Stainforth.

Talara, Peru.

9th February, 1954. 